Mągorzata RygielsKa

Uniwersytet Śląski w Katowicach

\title{
„BrexLit” po włosku dla dzieci i dorosłych: Rosie e gli scoiattoli di St. James oraz La mia Londra Simonetty Agnello Hornby
}

\section{Brexit i „BrexLit”}

23.06.2016 roku odbyło się w Wielkiej Brytanii referendum dotyczące pozostania bądź opuszczenia struktur Unii Europejskiej. Nieznaczna większość uprawnionych do głosowania $(51,89 \%)$ opowiedziała się za rezygnacją z unijnego członkostwa (por. m.in. Shipman 2016). Udokumentowane i poprzedzone odpowiednimi traktatami odejście Wielkiej Brytanii formalnie dokonało się 31.01.2020 roku, ale sam brexit, jak za brytyjskimi politykami Peterem Wildingiem i Davidem Cameronem zwykło się skrótowo nazywać ten proces, wciąż trwa, a jego złożony charakter daleko wykracza poza uwarunkowania ekonomiczno-polityczne. Wydaje się oczywiste, że „Brexit nie pojawił się znikąd: jest kulminacją wydarzeń trwających od dziesięcioleci, których historyczne korzenie sięgają znacznie dalej”' (O’Rourke 2019: XXII), dalej niż do dziewiętnastowiecznych narodzin przemysłowego imperium i głębiej niż w kolonialną przeszłość (O’Rourke 2019: 37 i nast.).

We wstępie do książki zatytułowanej Brexit and Literature Robert Eaglestone przekonywał, że

Brexit nie jest tylko wydarzeniem politycznym, ekonomicznym i administracyjnym, ale przede wszystkim także wydarzeniem o znaczeniu kulturowym. Brexit wyrósł z kulturowych przekonań na temat Europy

1 Tłumaczenia tekstów, o ile nie zaznaczono inaczej, pochodzą od autorki artykułu. 
i Zjednoczonego Królestwa (UK), realnych bądź wyimaginowanych; spory przed, podczas i po referendum były i wciąż są sporami dotyczącymi kultury; jego wpływ na życie na Wyspach (the cultural life of these islands) może trwać przez pokolenia (Eaglestone 2018:1).

Jednocześnie Eaglestone starał się zwrócić uwagę na znaczenie badania literatury jako potencjalnego źródła wiedzy o rzeczywistości kulturowej. Można bowiem z powodzeniem śledzić wpływ brexitu na literaturę współczesną (szczególnie jeśli przyjmiemy, że jest ona zarówno szczególnie czułym „barometrem zmian”, uprzywilejowaną platformą polemik, jak i rezerwuarem opisów pożądanych bądź negowanych wzorów zachowań, idei i wartości), można także zastanawiać się nad funkcją inferencyjną dzieł promujących określone postawy i poglądy. Eaglestone, choć nie opowiada się wyraźnie po stronie ani socjologii, ani antropologii literatury, zaznacza, że „literatura i jej badanie pełnią kluczową rolę w refleksji nad tym, w jaki sposób żyjemy jako jednostki i jako wspólnoty" (Eaglestone 2018: 2). To właśnie literatura pomaga w rozpoznaniu, dookreśleniu i zrozumieniu, „kim jesteśmy” i „co robimy”, często wskazuje także - wprost lub implicite - motywacje naszych działań.

Kristian Shaw mianem „BrexLitu” określa natomiast literaturę, która „bezpośrednio bądź aluzyjnie nawiązuje do wyjścia Wielkiej Brytanii z UE albo też dotyczy późniejszych konsekwencji społeczno-kulturowych, ekonomicznych, rasowych [...]" (Shaw 2018: 18, por. Shaw 2012; Everitt 2012) tej decyzji. Do prac tego nurtu zalicza więc również książki wydane dużo wcześniej, na przykład „eurosceptyczną powieśc”” The Ambassador (Ambasador) Edwiny Currie (1999), pisarki i byłej członkini Brytyjskiego Parlamentu, oraz dzieła w mniej lub bardziej bezpośredni sposób wiążące się z problematyką różnorodności kulturowej, akulturacji, czy podejmujące zagadnienia tak istotne jak współczesne formy nacjonalizmu (por. Moss 2018).

Badacze zajmujący się nurtem „BrexLitu” nie wymieniali jak dotąd prac innych niż anglojęzyczne, a wzmianki o literaturze dla dzieci dotyczyły wyłącznie utworów o charakterze parodystycznym (Witen 2021: 145-166). Jako jeden z najbardziej reprezentatywnych przykładów „BrexLitu” często przywołuje się Autumn Alie Smith (2016). Jesień (wyd. pol. 2020), którą nazwano „pierwszą powieścią po brexicie" (Kavenna 2016; Rau 2018: 31-44), można interpretować, o czym przekonuje Harald Pittel, jako powieść o dorastaniu, a zarazem literacką ewokację kulturowych wyobrażeń starości i dojrzewania umieszczoną w rzeczywistości po brytyjskim referendum (Pittel 2021: 121-143)². Powieść innej

2 Podobnie, jako powieść o dorastaniu, Pittel interpretuje ostatnią część tetralogii Smith, zatytułowaną Summer (2020), za którą autorka w 2021 roku otrzymała nagrodę Orwella. 
szkockiej pisarki, Sarah Moss, zatytułowaną Ghost Wall (2018; Mur duchów 2020) także można interpretować zarówno jako przedstawione w formie paraboli rozważania nad przyczynami brexitu, jak i narrację, w której odnaleźć można schemat typowy dla gatunku coming of age: główną bohaterką jest dorastająca, kilkunastoletnia Silvie, która podczas obozu archeologicznego zorganizowanego przez jej ojca, dumnego Brytyjczyka, ma poznawać sposób życia swych przodków. Jednocześnie zmaga się z problemami wieku dojrzewania związanymi z emocjonalnym uniezależnianiem się od rodziców, kształtowaniem poczucia własnej tożsamości, wartości i autonomii (Witen 2021: 146).

Na tym tle książki Simonetty Agnello Hornby: Rosie e gli scoiattoli di St. James (Rosie i wiewiórki z parku św. Jakuba) i La mia Londra (Mój Londyn) można uznać za dwa dopełniające się warianty ujęć problemu brexitu. Pierwsza z nich przeznaczona jest przede wszystkim dla dzieci w wieku szkolnym, choć autorka zaznacza, że warto do lektury zaprosić także dorosłych, zwłaszcza jeśli młody czytelnik uzna, że nie wszystko jest dla niego w pełni zrozumiałe. To właśnie „dziecko jest [tutaj - M.R.] pełnoprawnym odbiorcą wpisanym w tekst” (Wieczorkiewicz 2017: 67), do jego możliwości poznawczych dostosowana jest forma i treść książeczki. Hornby nie ukrywa, że jedną z najważniejszych kwestii, także ze względu na osobiste doświadczenia, jest dla niej sytuacja imigrantów w Wielkiej Brytanii. Istotne są pytania o to, jak można się zachować w obliczu silnie spolaryzowanych postaw wobec różnorodności kulturowej, narodowej i etnicznej, a także jak wychowywać dzieci w zglobalizowanej rzeczywistości. W Rosie e gli scoiattoli... pytania te zawarte są implicite, a starannie dobrane postaci zwierzęce uosabiają zwalczające się obozy o przeciwstawnych poglądach. W La mia Londra Hornby stawia je wprost, choć często pozostawia bez odpowiedzi, licząc na aktywność dorosłych czytelników, którzy stają przed problemami, ale i możliwościami, jakie wyłaniają się ze styku kultur, ich kontaktu, wreszcie długotrwałych procesów migracji.

Obszarem badawczym, na którym koncentruję się w tym artykule, są przede wszystkim zjawiska akulturacji (przebieg procesu akulturacji, jej strategie i mechanizmy -w wymiarze zarówno jednostkowym, jak i zbiorowym (Rudmin, Wang, Castro 2017: 75-953)) i bikulturalizmu (por. West i in. 2017: 963-990; Nguyen, Rule 2020: 258-271). Interesują mnie ich literackie opisy i interpretacje zawarte w dwóch, wzajemnie się dopełniających dziełach Hornby, które - choć napisane w języku włoskim - ze względu na czas wydania oraz eksponowaną

Summer rekomendowano jako „niezbędną lekturę dla każdego, kto chce zrozumieć nastrój Wielkiej Brytanii w tym burzliwym czasie" (Flood 2021).

3 Bibliografia dotycząca akulturacji w naukach o kulturze, psychologii i socjologii jest obszerna. Por. zestawienie prac o akulturacji i bikulturalizmie: Castro, Rudmin 2020. 
w nich problematykę wpisują się w nurt „BrexLitu”. Podstawowe pytania badawcze dotyczą tego, jak autorka - wieloletnia imigrantka - przedstawia w nich przebieg procesu adaptacji do życia w kulturze innej niż rodzima, które strategie przystosowawcze wybiera bądź waloryzuje pozytywnie, które natomiast poddaje krytyce. Akulturacja definiowana jest najczęściej jako „proces zmian spowodowanych międzykulturową wymianą lub przepływem treści" (Posern-Zieliński 1987: 17). Co istotne,

[...] przekształcenia te polegają na adaptacji obcych treści do własnej kultury, na eliminacji niektórych treści rodzimych, na modyfikacji (restrukturyzacji) elementów pozostałych i na tworzeniu treści synkretycznych, co w efekcie prowadzi do wzrostu podobieństw i zmniejszania się różnic w kontaktujących się systemach (Posern-Zieliński 1987: 17).

W najnowszej literaturze przedmiotu (Ferguson, Iturbide, Raffaelli 2020: 433) podkreśla się różnice pomiędzy akulturacją w ujęciu psychologicznym (por. Graves 1967; Berry 1997), badaną w odniesieniu do przemian w życiu poszczególnych jednostek, a akulturacją kulturową, dotyczącą całych zbiorowości ${ }^{4}$. Dzieła Hornby oferują wgląd w oba wymiary tak pojmowanej akulturacji. W La mia Londra, autobiograficznym przewodniku po Londynie, znajdziemy zarówno opisy indywidualnych przeżyć i doznawanych emocji, towarzyszących autorce podczas kilkudziesięcioletniego pobytu w tym mieście, jak i uwagi dotyczące wspólnot imigranckich (Jamajczyków mieszkających w Brixton, Polaków, Szkotów, a także Włochów), czynione z pozycji zewnętrznego obserwatora. Hornby zwraca uwagę na różnice w ich statusie społecznym, przynależność do określonych grup zawodowych, odmienną sytuację ekonomiczną (wspomina także o biednych imigrantach, w tym - bezdomnych), wskazuje na trudności

4 Dysktuje się również nad zasadnością propozycji Roberta Redfielda, Ralpha Lintona i Melvilla Herskovitsa, którzy uznali, że „akulturacja obejmuje te zjawiska, które następują, gdy grupy jednostek, mających różne kultury, wchodzą w bezpośrednie kontakty, wraz z późniejszymi zmianami we wzorcach kulturowych jednej lub obu grup" (cyt. za: Mikułowski-Pomorski 2012: 120; por. Kwaśniewski 1982). Współcześnie podkreśla się, iż w kulturze globalnej nie musi dochodzić do długotrwałych bezpośrednich kontaktów i oprócz tego typu akulturacji (nazywanej proximal acculturation lub immigration-based proximal acculturation) wskazuje się na „nowoczesną formę akulturacji nieimigracyjnej inspirowaną przez pośredni i/lub przerywany kontakt międzykulturowy”, który umożliwiają wysoko rozwinięte technologie komunikacyjne. Określa się ją mianem remote acculturation lub globalization-based remote acculturation (Ferguson, Iturbide, Raffaelli 2020: 431-460; Lefringhausen $\mathrm{i}$ in. 2021: 56-57). 
$\mathrm{w}$ procesie integracji z rodowitymi londyńczykami. Zainteresowana dziejami „włoskiej migracji” do Wielkiej Brytanii, przekonuje, iż co najmniej od roku 1290, kiedy to „po wygnaniu Żydów przez Edwarda I Lombardczycy przejęli ich «handel pieniężny»" (Hornby 2017: 251), można datować obecność Włochów w Londynie. Podkreśla, że według niej różnorodność kulturowa i etniczna, z którą styka się w tym mieście, może być uznana zarówno za jego siłę, jak i największą słabość. Nie kryje przy tym swoich poglądów dotyczących procesów migracyjnych i wprost oświadcza: „Oblicza się, że w roku 2030 połowa mieszkańców Zjednoczonego Królestwa będzie mieszanego pochodzenia (di sangue misto), tak, jak moje dzieci. To będzie wielka siła Wielkiej Brytanii, siła, która ma swoje źródło w Londynie" (Hornby 2017: 251).

Dotyka tutaj innego problemu szerzej podejmowanego w Rosie e gli scoiattoli..., a mianowicie bikulturalizmu. W najogólniejszym ujęciu bikulturalizm (dwukulturowość) oznacza biegłość zarówno w obszarze kultury rodzimej, jak i kultury kraju lub regionu, w którym ktoś się osiedlił. Odnosi się nie tylko do imigrantów, którzy przybyli z innych krajów, ale także do dzieci imigrantów, które - chociaż urodziły się wychowały w społeczeństwie przyjmującym - są prawdopodobnie głęboko zakorzenione w kulturze swych rodziców (Schwartz, Unger 2010: 28). Bikulturalizm bywa także definiowany jako „mieszanie się postaw, przyzwyczajeń, przekonań właściwych dla obu kultur” (Ferguson, Iturbide, Raffaeli 2020: 433). Przyjmuje się założenie, iż „ludzie mogą należeć do dwóch kultur bez konieczności poświęcenia wartości kultury rodzimej; integrują oni różne aspekty każdej z tych kultur" (Ferguson, Iturbide, Raffaeli 2020: 433), choć oczywiście dzieje się to w różnym zakresie i w dużej mierze zależy od indywidualnych doświadczeń. Syn Hornby na pytanie o to, czy czuje się bardziej Włochem, czy Anglikiem, odpowiada zazwyczaj: „londyńczykiem” (Hornby 2017: czwarta strona okładki). Doskonale odnajduje się zarówno w Wielkiej Brytanii, jak i w różnych regionach Italii, mówi płynnie w obu językach5. Wykazuje się przy tym, podobnie jak jego matka, szeroką gamą kompetencji komunikacyjnych, wymagających znajomości obu kultur (por. Chen, Bnet-Martinez, Bond 2008).

W Rosie e gli scoiattoli..., opowieści przeznaczonej dla dzieci, mieszkające w parku zwierzęta symbolizują przedstawicieli różnych kultur i grup etnicznych, a stopień ich integracji ze środowiskiem, w którym aktualnie przebywają, w dużej mierze zależy od wypracowywanych, często przez kilka generacji, strategii akulturacyjnych (asymilacji, separacji, integracji bądź marginalizacji, por. Berry 1997), które bywają powielane, bądź też - zwłaszcza w czasie poprzedzającym

5 Na temat związków bikulturalizmu i bilingwizmu por. m.in. Grosjean 2019. 
referendum - kontestowane przez potomków. Główna bohaterka - dziewięcioletnia Rosie - wywodzi się z rodziny, której żaden z członków nie należy do „kultury przyjmującej”, można by więc tutaj mówić nie tylko o bikulturalizmie, ale także o wielokulturowości (por. Titzmann, Jugert, red. 2020).

\section{Mój Londyn: od zachwytu do stabilizacji}

„Nie umiałabym wyrazić lepiej wyrazić mej miłości do Londynu niż Samuel Johnson, najbardziej znany uczony angielski xviII wieku" (Hornby 2017: 5) wyznała Hornby, autorka poczytnych powieści, w tym tryptyku La Mennulara. Johnson, który zasłynął przede wszystkim jako autor A Dictionary of the English Language (1755), powiedział u schyłku życia swemu biografowi, Jamesowi Boswellowi: „[... ] kiedy człowiek jest zmęczony Londynem, to jest także zmęczony życiem, ponieważ Londyn zapewnia wszystko, co życie może zaoferować [...]. Nie znajdzie Pan żadnego myślącego człowieka, który chciałby opuścić Londyn" (Hornby 2017: 5).

Właśnie jego słowa przytacza na początku swej książki La mia Londra (2017), wydanej w rok po referendum, Hornby, rodowita Palermitanka, od kilkudziesięciu lat mieszkająca w Londynie. Chociaż początkowo wątpiła, że zdoła się nauczyć angielskiego, a Anglię znała głównie z prac André Mauroisa i powieści Jane Austin, to właśnie tutaj ukończyła staż zawodowy, wyszła za mąż, urodziła dwóch synów i jako wykwalifikowany adwokat ds. opieki nad dzieckiem (Child Care Solicitor) założyła własną firmę prawniczą, zajmującą się adopcją oraz opieką nad małoletnimi (Hornby 2017: 11-60). Nawet jeśli pierwsza część $\mathrm{w}$ dużej mierze autobiograficznej opowieści nosi tytuł Un’aliena a Londra (Obca $\mathrm{w}$ Londynie) $)^{6}$, to nie znajdziemy tutaj opisów doznań związanych z szokiem kulturowym (Oberg 1960), bohaterka nie przeżywa też euforii „miodowego miesiąca" (Berry 2003: 17-37), kiedy to, co nowe i w sposób zauważalny odmienne od wzorów znanych z kultury rodzimej, staje się obiektem zainteresowania, a nierzadko zachwytu. Hornby wspomina, że kiedy w 1975 roku uaktualniano spis Włochów mieszkających w Londynie, myślała o sobie jak o „imigrantce w ścisłym znaczeniu tego słowa - kimś, kto opuszcza własny kraj, aby prędzej czy później osiedlić się w innym" (Hornby 2017: 116). Jednocześnie przyznaje:

nie czułam się inna niż Włosi ani oddalona od Sycylijczyków [...]: w domu mówiło się po włosku i zawsze byli tu goście z Palermo.

[...] Być może prawda była również taka, że brakowało mi i czasu,

6 Na temat kategorii swój- obcy w języku polskim i angielskim por. Gomóła 2017: 112. 
i przestrzeni, by mieć poczucie wykluczenia bądź izolacji. Byłam częścią angielskiej społeczności, miałam przyjaciół ze wszystkich kontynentów i wielu karaibskich klientów (Hornby 2017: 116).

Wielokrotnie też podkreśla podwójną przynależność: do Londynu i do Palermo (Hornby 2017; Hornby, Cuticchio 2019). W jej przypadku można więc mówić o bikulturalizmie, który wiąże się z „poczuciem komfortu i sprawnym poruszaniem się zarówno w obszarze rodzimej kultury, jak i kultury bądź regionu [...], w którym się osiedliła” (Schwartz, Unger 2010: 26). Co więcej, „termin ten ma zastosowanie nie tylko $\mathrm{w}$ odniesieniu do imigrantów, pochodzących z różnych krajów, ale także do ich dzieci" (Schwartz, Unger 2010: 26), często wychowywanych w atmosferze poszanowania dla innych kultur, a zarazem uczonych tego, by umiejętnie rozpoznawały i doceniały własne kulturowe dziedzictwo.

\section{Mój Londyn: dynamika zmiany}

Hornby ma świadomość, że na jej stosunek do Londynu wpływają osobiste przeżycia i emocje, a jej sympatia do miasta nie ma wymiaru uniwersalnego. Stara się jednak przekonać czytelników, że jest to miejsce otwarte na różnorodność, oferujące każdemu, co najlepsze. Dowodów szuka w przeszłości, w historii kultury:

Historycznie Londyn wspierał, przyjmował i wchłaniał (assorbire) imigrantów, zarówno wewnętrznych (z całej Anglii, także innych narodowości niż Królestwo), jak i zewnętrznych. Zawsze ich potrzebował, od czasów średniowiecza: warunki sanitarne były tak okropne, że aż do 1870 roku zmarli znacznie przewyższali liczbą nowonarodzonych i miasto przeżywało - nie tylko z punktu widzenia ekonomicznego dzięki imigrantom $\mathrm{z}$ całego świata. W dziewiętnastym wieku Londyn był celem podróży Żydów, karbonariuszy i dysydentów politycznych uciekających z absolutystycznych państw Europy, a także tych, którzy poszukiwali pracy. Wszyscy byli mile widziani (Hornby 2017: 64).

Poszukując argumentów udowadniających jej tezę, sięga zarówno do uogólnień, jak i do jednostkowych przykładów, wspominając chociażby kariery takich postaci, jak Beniamin Disraeli, Dababhai Naoroji, Nicolas Constantin czy David Pitt, którzy pomimo obcego pochodzenia, różnic kulturowych (w tym religijnych i etnicznych) doskonale odnaleźli się w nowej rzeczywistości, nie zapominając o własnym dziedzictwie (Hornby 2017: 64-65). Ten apologetyczny 
fragment znajduje się w części poświęconej zamieszkom w Brixton w 1981 i 1985 roku, a kończy go retoryczne, a zarazem pełne zdziwienia pytanie: „Dlaczego Londyn, tak liberalny, tak bardzo się zmienił?” (Hornby 2017: 65). Hornby nie pozostaje bynajmniej bezkrytyczna, świadczą o tym zarówno metaforyczne tytuły rozdziałów, na przykład Una nazione di di sange misto. Imigrazione, gang e intolleranza (Naród mieszanej krwi. Imigracja, gangi i nietolerancja), ale także problematyka aneksów, z których jeden poświęcony jest zjawisku imigracji włoskiej w Londynie. Hornby wspomina także o specjalnie wydzielonych dzielnicach imigranckich (Hornby 2017: 129-131, 251-256). Podstawą do rozważań są w opowieści nie tylko jej obserwacje i przemyślenia, ale także dane statystyczne dotyczące demografii, zróżnicowania etnicznego ludności, wielości używanych języków, a nawet pokoleniowych strategii migracyjnych:

Dzisiaj na populację Londynu składa się osiem i pół miliona mieszkańców, z czego 44,9 procent to ludzie biali i obywatele brytyjscy. Mówi się tu w trzystu językach, jest tu pięćdziesiąt grup etnicznych z więcej niż dziesięcioma tysiącami członków. W ostatnich dwudziestu latach liczba dzieci rezydentów Wielkiej Brytanii urodzonych za granicą odpowiada jednej trzeciej całkowitej liczby urodzeń (Hornby 2017: 130).

Wielu z tych ludzi mierzy się z problemami związanymi z próbą adaptacji do odmiennych warunków kulturowych, ich jednostkowe biografie skrywają się za liczbami, czasem wzbudzają zainteresowanie pisarzy, niekiedy socjologów, a także - co nie mniej ważne - antropologów kultury, przekonanych o wadze badań jakościowych, opartych o mniej lub bardziej zestandaryzowane wywiady kwestionariuszowe.

\section{Przygoda w parku}

Problemy związane z przystosowywaniem się do innej kultury dotyczą nie tylko potomków Hornby, ale także bohaterki jej najnowszej książki, Rosie e gli scoiattoli di St. James, tytułowej Rosie, córki Włocha i Jamajki, która w dzień referendum dotyczącego pozostania Wielkiej Brytanii w Unii Europejskiej staje się niespodziewanie świadkiem obrad parlamentu zwierząt w królewskim parku, a także walk jego mieszkańców: wiewiórek (przybyłych z Ameryki Północnej), pelikanów (przywiezionych z Rosji) i papug z lisami - autochtonami. Ich poglądy, zachowania i decyzje pozwalają Rosie - w sposób adekwatny do jej wieku - zetknąć się z dylematami, ale i potencjałem, jaki niosą ze sobą procesy akulturacji, adaptacji, a nawet - asymilacji. 
Rosie Giuffrida-Watson, zwana „Gadułą”, pomimo iż rodzice powtarzali jej, że jest wyjątkowa, czasami czuła się inna: różniła się od innych dzieci wyglądem, posługiwała się biegle trzema językami (włoskim, angielskim i patois - jamajskim) i była niezwykle rezolutna. W dzień referendum rodzice zabrali ją na piknik do parku. Wycieczka odbywała się jednak w atmosferze napięcia, nieznanego dotąd poruszenia, częstych dyskusji, w których powtarzały się niezrozumiałe słowa: „Od kilku miesięcy w Londynie wiele mówiło się o referendum, specjalnym głosowaniu, w którym pytano mieszkańców, czy Wielka Brytania ma pozostać w Unii Europejskiej, czy nie. Rosie nie rozumiała zbyt dobrze, czym miałoby być to referendum" (Hornby 2018: 37, podkr. M.R.).

Dzieci na szkolnych podwórkach grały w piłkę, zamiast „Dalej, Real!” i „Gola, Atletico!” wykrzykując: „Naprzód, Brexit!”, „Odwagi, Remain!”. Rodzice spierali się o wyniki głosowania i martwili o przyszłość. Rosie nie raz była świadkiem ich sporów. Kiedy Bruno przekonywał:

Lud tych wysp pochodzi z Europy. Anglosasi wywodzą się z plemion germańskich o korzeniach sięgających terenów współczesnej Holandii, podczas gdy Normanowie, którzy przybyli tu zaraz po nich, pochodzili ze Skandynawii, skąd przenieśli się do Francji. Nie wspominając już o obecnej rodzinie królewskiej (Hornby 2018: 54),

Brenda, bardziej sceptyczna, odpowiadała:

A więc w ogóle nie rozumiesz Anglików! Jesteś tutaj od ponad dziesięciolecia i jesteś w stanie dostrzec tylko ich historię, i myślisz, że wszyscy jesteśmy Londyńczykami! A wcale tak nie jest. Ja się tu urodziłam i mogę cię zapewnić, że dla wielu w tym kraju wszystko, co jest odmienne, wzbudza strach. Wystarczy, że zobaczą kogoś, kto minimalnie różni się od grupy, już patrzą na niego podejrzliwie [...]. Zapomniałeś o historiach, które opowiadała moja matka? A może nigdy ich nie słuchałeś (Hornby 2018: 56),

a emocjonalną wymianę zdań nierzadko przerywał ktoś obcy. 23.06.2016 roku zrobił to sprzedawca orzechów, próbując pogodzić zwaśnionych małżonków. Przekonywał: „Teraz jesteście Londyńczykami, tak, jak ja” (Hornby 2018: 53). To on właśnie wyjaśnił Rosie, dlaczego od pewnego czasu nie widuje się już wiewiórek w parku świętego Jakuba: „Według mnie wszystko to wina referendum. My jesteśmy zmęczeni, a i one mają już dość" (Hornby 2018: 51). Opiekun ptaków, znajdując opuszczone gniazda, także zastanawiał się, co takiego dzieje się 
w słynnym parku. Kiedy spotkał małą dziewczynkę, wypytującą o mieszkające tu zwierzęta, z przyjemnością opowiedział:

szare wiewiórki są nowymi przybyszami z Ameryki. Pierwsze z nich, jako żyjąca ozdoba ogrodu, zostały podarowane jedenastemu księciu Bedford zaledwie półtora wieku temu. To on przyniósł je tutaj, by zapewnić rozrywkę odwiedzającym park. Wraz z upływem pór roku kolonia szarych powiększała się, zajmując przestrzeń rudych, miejscowych wiewiórek. Teraz są wszędzie, w parkach i lasach miasta i całego państwa. Nie tak, jak pelikany, które przybyły tu z Rosji prawie cztery wieki temu, także jako dar od ambasadora, i żyją wyłącznie w tym parku (Hornby 2018: 70).

Ta wiedza przydała się Rosie, kiedy przysłuchiwała się dyskusjom w „Parlamencie Korony”, toczonym pod osłoną gałęzi wiekowego dębu. Wydawało się, że istniejące tu zasady odzwierciedlają te znane z ludzkiego świata. Niemal każda grupa miała tutaj swoich przedstawicieli:

W niektórych lożach były wiewiórki z białym pasem, biegnącym nad pyszczkiem od jednego policzka do drugiego. W innych - wiewiórki z długim kosmykiem, który sięgał znad czoła do karku, oraz wiewiórki, które nosiły dookoła głowy opaskę z czarnym piórem (Hornby 2018: 84).

Byli to reprezentanci trzech różnych plemion: Adamantów, Pnuków i Siouxów, pochodzących z obszarów zamieszkałych niegdyś przez „czerwonoskórych” Indian. Admirał, kierujący obradami i przewodniczący Radzie Wojennej, zaznaczył:

Moja rodzina [...] przybyła do Anglii na pokładzie statków, które przewoziły drewno, skóry i bawełnę z Północnej Ameryki. Moim przodkom tak bardzo podobała się morska podróż, że pozostawały na statkach przez lata. Mój dziadek i moja babcia urodzili się na pokładzie. [...] Teraz jednak wszyscy jesteśmy mieszkańcami tego parku, a ten dąb jest naszym domem (Hornby 2018: 85).

Papugi, pelikany i wiewiórki wspólnie zastanawiały się, jak dać odpór lisom, które uważały się za wyłącznych i prawowitych gospodarzy, a jednocześnie nie kryły niechęci i lęku wobec tych, których uznawały za przybyszów - intruzów i uzurpatorów, zawłaszczających ich własny teren i przeznaczone dla nich dobra: 
[...] utrzymywały, że ich pobyt tutaj sięga czasów, kiedy tereny parku św. Jakuba były królewskim rezerwatem zwierzyny łownej. Były zaniepokojone, ponieważ park stawał się przepełniony zwierzętami imigrantami oraz ptakami, które ani nie pochodzily z parku, ani nawet z Królestwa. Dopóki liczba nowych przybyszy była ograniczona, istniała możliwość, by ich zintegrować, ale teraz, kiedy było ich już zbyt wielu, i jeśli dalej tak by się działo, to miejscowe zwierzęta takie jak one stałyby się mniejszością, gośćmi we własnym domu. Zacznijmy od tego, że wiewiórki zabierały wszystkie przysmaki przyniesione przez odwiedzających i dla szczurów nic już nie zostawało. Tylko lisy dbały o nie, wykradając ze śmietników. I tak, lisy i szczury zjednoczyły się w polowaniu na intruzów, by odesłać ich do ich domów raz na zawsze (Hornby 2018: 87-88).

Interesujący jest opis przemyśleń małej Rosie w odpowiedzi na opowieści, których:

[...] słuchała z uwagą, ale nie była pewna, czy dobrze je rozumie. Park wydawał jej się ogromny i wcale nie była przekonana, czy wyrzucenie wiewiórek przyniosłoby tak wielkie korzyści szczurom. Poza tym, jak mówił jej ojciec, czy sami Anglicy nie byli wszyscy po trosze mieszaniną miejscowych i obcych? (Hornby 2018: 88).

Bohaterka próbowała połączyć wiedzę czerpaną z rozmów i opowieści dorosłych z tym, co działo się wśród zwierząt parku św. Jakuba: przybyszy i autochtonów. Dzięki przygodzie w parku Rosie ma okazję zetknąć się z polaryzacją stanowisk dotyczących brexitu obecną w świecie zarówno ludzkim, jak i zwierzęcym. Jednocześnie dostrzega, że wzrost liczby imigrantów może wzbudzać krańcowo różne reakcje tak wśród „przybyszy”, jak i przedstawicieli „kultury przyjmującej”: od obaw aż po rozumiejącą akceptację. Bohaterka spotyka się z przychylnością Pani Draper, która jako pierwsza opowiedziała jej o tajemniczym zniknięciu wiewiórek z parku św. Jakuba, a także z życzliwością i pomocą opiekuna ptaków. Przysłuchuje się rozmowom rodziców z rodowitymi Londyńczykami, którzy jak sprzedawca cukierków - wydają się otwarci na kulturową różnorodność i dostrzegają zalety obecności imigrantów w ich ukochanym mieście.

W tej książce w zdecydowanie większym stopniu niż w La mia Londra Hornby zwróciła uwagę na problem, który coraz częściej dostrzegają także badacze akulturacji, a mianowicie na to, „w jaki sposób członkowie grup większościowych (majority group members), tacy jak obywatele kraju gospodarza, odnoszą się do kultury imigrantów" (Lefringhausen i in. 2021: 56), co stoi u podstaw ich 
zachowań oraz w jakim stopniu i zakresie sami podlegają procesom adaptacji do innych kultur. Pozwoliła także czytelnikom, na przykładzie przemian zachodzących w zwierzęcym świecie w dniu referendum, przyjrzeć się odmiennym strategiom akulturacji: odnaleźć można tu bowiem przykład asymilacji, wiązanej z całkowitym odrzuceniem bądź zaprzeczeniem własnego dziedzictwa (jednostkę w pełni zasymilowaną reprezentuje tu wiewiórka Filomena, która kiedyś, tak jak Rosie, była małą dziewczynką), a następnie świadomym dążeniem do integracji (plemiona wiewiórek, współpracujące z grupą pelikanów i papug). Pomijane są tutaj aspekty „zarządzania integracją imigratów” - autorka podkreśla bowiem przede wszystkim sprawczość przybyszy i rolę aktywnej współpracy w budowaniu nowej - w założeniu przyjaznej dla wszystkich - rzeczywistości, w której dwukulturowość, a także wielokulturowość postrzegane są raczej jako szansa na rozwój harmonijnych relacji niż potencjalne zagrożenie dla własnej kultury.

\section{Pochwała wspólnoty, pochwała różnorodności - dwie odsłony}

Obie książki Hornby, choć każdą z nich można by wpisać w nurt „BrexLitu”, znacząco się od siebie różnią pod względem genologicznym, skierowane są również potencjalnie do innych odbiorców. Jednocześnie ich główny przekaz wydaje się zaskakująco podobny: to zarazem pochwała wspólnoty i pochwała różnorodności. W La mia Londra czytelnik wierzy Hornby na mocy autobiograficznego paktu (Lejeune 2007), a autorka legitymizuje swą wiedzę, sięgając po źródła historyczne i współczesne dane o charakterze demograficznym. W umiejętny sposób łączy opisy własnych odczuć, emocji i ekspresję wątpliwości z informacjami o charakterze faktograficznym, nie naruszając przy tym toku ani spójności zsubiektywizowanej narracji. Wyraźnie - jako osoba o podwójnych korzeniach, deklarująca przynależność z urodzenia i z wyboru do dwóch różnych kultur - opowiada się za tolerancją, poszanowaniem godności człowieka, równością, życzliwością, otwarciem na drugiego człowieka.

7 Tę kwestię podniesiono m.in. w specjalnym numerze czasopisma „Comparative Migration Studies” (por. Saharso 2019), którego hasłem przewodnim było pytanie: „Kto potrzebuje integracji?”. Punktem wyjścia do debaty naukowców stała się książka Willema Schinkela (2017), której autor zajmował się m.in. analizą funkcjonowania pojęć takich jak integracja i multikulturalizm w dyskursie publicznym oraz w naukach społecznych, a także społecznymi mechanizmami dystrybucji i produkcji wiedzy. To jednak odrębne problemy badawcze. 
Odnalazła je u Samuela Johnsona ${ }^{8}$, o którym Tomasi di Lampedusa pisał, jak zauważyła Hornby, w sposób „nieco przesadzony, typowy dla anglofila”: ten człowiek „jest Anglią" (Hornby 2018: 85).

W książce przeznaczonej dla dzieci, bogato ilustrowanej i tylko z pozoru obciążonej nadmiernym dydaktyzmem, podkreśla wagę tych samych wartości. Stara się też podjąć problem doświadczania, poznawania i kategoryzowania rzeczywistości kulturowej przez dzieci w wieku szkolnym, a jednocześnie skłania je do rozmów $z$ dorosłymi, którym warto nieustępliwie zadawać ważne pytania (Hornby 2018: 123).

Co ciekawe, zarówno w La mia Londra, jak i w Rosie pojawia się ciekawy zabieg opowiadania o dziedzictwie kulturowym przy okazji opisu zwiedzanych lub obserwowanych właśnie miejsc bądź artefaktów. Na subiektywną mapę miasta składają się także elementy krajobrazu: „Tamiza nauczyła mnie historii Londynu lepiej niż książki i muzea. Objaśnia mi, dlaczego miasto znajduje się tu, gdzie jest, i jak się rozwijało" (Hornby 2017: 207), wyznaje Hornby, opisując jeden ze swoich pieszych spacerów po Londynie. Z chęcią odwiedza też muzea, także pomniejsze, jak chociażby to urządzone w domu Johna Soane’a przy Lincoln in Fields, przekonana, że prywatne wnętrza „mówią turystom o właścicielach domu tak, jakby były ich przodkami, opowiadają anegdoty tak, jakby to były historie ich rodziny" (Hornby 2017: 218), w sposób pośredni umożliwiają wgląd w codzienne życie ludzi minionych wieków.

Bruno natomiast, zabierając Rosie na wycieczkę autobusem, który prowadzi, proponuje córeczce następującą zabawę:

Trasa tego autobusu jest antyczna i zawiła. Stary Burt mówi, że wyznacza granicę energii Druidów pomiędzy kamiennym kręgiem Stonehenge a Wielkim Murem Chińskim. Wydaje się, że do dziś nikt nie zna jej dokładnego przebiegu ani liczby przystanków, nawet tak starzy kierowcy jak Burt. Przebyć całą trasę i policzyć, jeśli zdołasz to zrobić, właściwą liczbę przystanków pomiędzy Peckham a South Kensington (Hornby 2018: 10).

Ciekawska Rosie podejmuje wyzwanie. W czasie podróży, która dla jej ojca staje się pretekstem do opowiadania o historii Londynu i Wielkiej Brytanii, dowiaduje się wielu nowych rzeczy nie tylko o kraju i mieście, w którym mieszka. Uczy się także krytycznego myślenia. Kierowca opowiada jej bowiem

8 Oczywiście ten zestaw cech może być uznany za dyskusyjny, Hornby przyznaje jednak, że traktuje Johnsona jak swoje „bóstwo opiekuńcze” (Hornby 2017: 83-93). 
nie tylko o czerwonych piętrowych autobusach, które „nawet jeśli teraz stały się symbolem Londynu i Anglii, tak jak Królowa i Big Ben, to w istocie «narodziły się w Paryżu»", o dynastii Windsorów wywodzącej się z rodu Saxe-Couburg-Gotha, o Florence Nightingale, założycielce szpitala św. Tomasza, a także o lwach na Trafalgar Square. Podczas wizyty w National Gallery pokazuje Rosie - na przykładzie obrazu Holbeina Ambasadorowie - jak wiele w postrzeganiu tego, co widzimy, zależy od przyjętej perspektywy oglądu (Hornby 2018: 31-47). Nie bez powodu też zapewne niezwykłe spotkanie ze zwierzęcym parlamentem (nota bene zwanym „Parlamentem Korony” (Il Parlamento della Chioma), Hornby 2018: 81-94) odbywa się w parku św. Jakuba, który został wpisany na listę angielskiego dziedzictwa narodowego. Hornby, choć nie wprost, stawia więc pytania nie tylko o kulturową tożsamość, ale także o to, co i dlaczego uznajemy za własne dziedzictwo kulturowe, materialne i niematerialne. Być może także dlatego Hornby zdecydowała się także wydać inną wersję autobiograficznego przewodnika, tym razem napisaną wespół z jednym z synów i zatytułowaną $L a$ nostra Londra (Nasz Londyn, Hornby, Hornby 2020).

Książki Hornby nie zostały dotąd przetłumaczone na angielski, jedyną przeszkodą w ich szerszej recepcji może być zatem bariera językowa. Rosie e gli scoiattoli może okazać się przydatną lekturą nie dla tylko imigrantów i ich dzieci, w tym chociażby członków wspólnot włoskich w Londynie, ale także dla imigranckich wspólnot we Włoszech, które nierzadko stykają się z podobnymi problemami, wynikającymi w dużej mierze ze starcia kulturowych różnic (Riccio 2014; Amato, Gatti 2018: 1-12). Osobnym wyzwaniem - i dla dzieci, i dla dorosłych - jest rekonstrukcja drzewa genealogicznego, którego schemat znajduje się na ostatnich kartach utworu wraz z zachętą: „Każdy z nas, tak jak Rosie, ma takie drzewo i każde z nich jest inne, spróbuj odtworzyć twoje!" (Hornby 2018: 124-126). To wymaga postawienia pytań o to, skąd pochodzisz, kim jesteś, dokąd zmierzasz, kim są twoi przodkowie i twoja rodzina, kim chcesz zostać w przyszłości, jakie jest twoje kulturowe dziedzictwo.

\section{| Bibliografia}

Amato Fabio, Gatti Rosa (2018), Insegnare le migrazioni internazionali in Italia: uno sguardo allantropologia e alla geografia, „Enseigner les migrations internationals", nr 17, s. 1-12, https://doi.org/10.400o/e-migrinter.1230.

Berry John W. (1997), Immigration, acculturation, and adaptation, "Applied Psychology", t. 46, nr 1, s. 5-34, https://doi.org/10.1111/j.1464-0597.1997.tbo1087.x. 
Berry John W. (2003), Conceptual Approaches to Acculturation, w: Acculturation. Advances in Theory, Measurement, and Applied Research, red. Kevin M. Chun, Pamela Balls Organista, Gerardo Marin, American Psychological Association, Washington, s. 17-37.

Castro Joaqim, Rudmin Floyd (2020), Multinational Bibliography on Acculturation (1808-2020), with URL Links to Abstracts or Full-text Links to Abstracts or Full-text, "Online Readings in Psychology and Culture", t. 8, nr 1, s. 3-7, https://doi.org/10.9707/2307-0919.1075.

Chen Sylvia Xiaohua, Bnet-Martinez Verónica, Bond Michael Harris (2008), Bicultural Identity, Bilingualism, and Psychological Adjustment in Multicultural Societies. Immigration-Based and Globalization-Based Acculturation, "Journal of Personality" 76, s. 803-838.

Eaglestone Robert (2018), Introduction: Brexit and Literature, w: Brexit and Literature Critical and Cultural Responses, red. Robert Eaglestone, Taylor\&Francis, London-New York, s. 1-6.

Everitt Dulcie (2021), BrexLit. The Problem of Englishness in Pre- and Post-Brexit Referendum Literature, Zero Books, https://tinyurl.com/3dsmzmtr [dostęp: 14.07.2021].

Ferguson Gail M., Iturbide Maria I., Raffaelli Marcela (2020), Proximal and Remote Acculturation. Adolescents' Perspectives of Biculturalism in Two Contexts, "Journal of Adolescent Research" t. 35, s. 431-46o, https://doi.org/10.1177/0743558419868221.

Flood Alison (2021), Ali Smith wins Orwell prize for novel taking in Covid-19 and Brexit, "The Guardian", 25.06, https://tinyurl.com/p4ehheav [dostęp: 9.07.2021].

Gomóła Anna (2017), Kindred, Alien, Other in the Analysis of Jan Michał Witort's Memoir, "Logos", nr 92, s. 112-119.

Graves Theodore D. (1967), Psychological acculturation in a tri-ethnic community, "Southwestern Journal of Anthropology", t. 23, nr 4, s. 337-350.

Grosjean François (2019), A Journey in Languages and Cultures.

The Life of a Bicultural Bilingual, Oxford University Press, Oxford, https://doi.org/10.1111/j.1467-6494.2008.00505.x.

Hornby Simonetta Agnello (2017), La mia Londra, Giunti Editore, Firenze-Milano.

Hornby Simonetta Agnello (2018), Rosie e gli scoiattoli di St. James, Giunti Editore, Firenze-Milano.

Hornby Simonetta Agnello, Cuticchio Mimmo (2019), Siamo Palermo, Mondadori, Milano.

Hornby Simonetta Agnello, Hornby George (2020), La nostra Londra, Giunti Editore, Firenze-Milano. 
Kavenna Joanna (2016), Autumn by Ali Smith review - a beautiful, transient symphony, “The Guardian”, 12.10, https://tinyurl.com/4f2ke49x [dostęp: 9.07.2021].

Kwaśniewski Krzysztof (1982), Zderzenie kultur. Tożsamość a aspekty konfliktów i tolerancji, PwN, Warszawa.

Lefringhausen Katharina i in. (2021), A new route towards more harmonious intergroup relationships in England? Majority members' proximal-acculturation, "International Journal of Intercultural Relations" nr 82, s. 56-73, https://doi.org/10.1016/j.ijintrel.2021.03.006.

Lejeune Philippe (2007) Wariacje na temat pewnego paktu. O autobiografii, przel. Regina Lubas-Bartoszyńska, Wincenty Grajewski, Universitas, Kraków.

Mikułowski-Pomorski Jerzy (2012), Jak narody porozumiewaja się ze sobq w komunikacji międzykulturowej i komunikowaniu medialnym, Universitas, Kraków.

Moss Sarah (2018), Ghost Wall, Granta Books, London.

Moss Sarah (2020), Mur duchów, przeł. Paulina Surniak, Wydawnictwo Poznańskie, Poznań.

Nguyen Angela-MinhTu, Rule Nicholas O. (2020), Implicit Biculturalism Theories: How Bicultural Individuals Perceive Others and Organize Their Own Cultures, "Identity. An International Journal of Theory and Research", t. 20, nr 4, 258-271, https://doi.org/10.1080/15283488.2020.1820868.

O'Rourke Kevin H. (2019), A short history of Brexit. From brentry to backstop, Pelican Books, London.

Oberg Kalervo (1960), Cultural Shock: Adjustment to New Cultural Environments, "Missiology. An International Review", t. 7, nr 4, s. 177-182, https://doi.org/10.1177/009182966000700405.

Pittel Harald (2021), Ali Smith's 'Coming-of-Age' in the Age of Brexit, w: Brexit and Beyond. Nation and Identity, red. Ina Habermann, Daniela Keller, Narr Francke, Attempto Verlag GmbH, Tübingen, s. 121-143.

Posern-Zieliński Aleksander (1987), Akulturacja, w: Słownik etnologiczny, red. Zofia Staszczak, pwn, Warszawa-Poznań, s. 16-19.

Rau Petra, Autumn After the Referendum, w: Brexit and Literature: Critical and Cultural Responses, red. Robert Eaglestone, Taylor\&Francis, London-New York, s. 31-44.

Redfield Robert, Linton Ralph, Herskovits Melville J. (1936), Memorandum on the Study of Acculturation, "American Antropologist", nr 38, s. 149-152.

Riccio Bruno (2014), Antropologia e Migrazioni, Roma, CISU.

Schwartz Seth J., Unger Jennifer B. (2010), Biculturalism and context: What is biculturalism, and when is it adaptive?, "Human Development", nr 53, s. 26-32, https://doi.org/10.1159/000268137.

Rudmin Floyd, Wang Bo, Castro Joaqim (2017), Acculturation research critiques and alternative research designs, w: The Oxford handbook of acculturation 
and health, red. Seth J. Schwartz, Jennifer Unger, Oxford University Press, Oxford, s. 75-95.

Saharso Sawitri (2019), Who needs integration? Debating a central, yet increasingly contested concept inmigration studies, "Comparative Migration Studies", nr 7, s. 1-3, https://doi.org/10.1186/s40878-019-0123-9.

Schinkel Willem (2017), Imagined Societies. A Critique of Immigrant Integration in Western Europe, Cambridge University Press, Cambridge.

Shaw Kristian (2018), BrexLit, w: Brexit and Literature Critical and Cultural Responses, red. Robert Eaglestone, Taylor\&Francis, London-New York, s. $15-30$.

Shaw Kristian (2021), British Literature and the European Project, Bloomsbury Academic, London [zapowiedź wydawnicza], https://tinyurl.com/z4erskdh [dostęp: 13.07.2021].

Shipman Tim (2016), All Out War. The Full Story of How Brexit Sank Britain's Political Class, William Collins, Glasgow.

Smith Ali (2020), Jesień, przeł. Jerzy Kozłowski, Wydawnictwo waB, Warszawa.

Smith Ali (2016), Summer, Hamish Hamilton, London.

Smith Neil (2000), The new urban frontier. Gentrification and the revanchist city, Routledge, London.

Titzmann Peter F., Jugert Philipp, red. (2020), Youth in superdiverse societies. Growing up with globalization, diversity, and acculturation, Routledge, London.

West Alexandria L. i in. (2017), More than the sum of its parts: A transformative theory of biculturalism, "Journal of Cross-Cultural Psychology", t. 48, $\mathrm{nr} 7$, s. 963-99o, https://doi.org/10.1177/0022022117709533.

Wieczorkiewicz Aleksandra, „Złoty wiek”: oddalenia, przekroje. 8 o lat anglosaskiej klasyki dla dzieci i 150 lat jej przekładów na język polski w trzech makroperspektywach, „Forum Poetyki / Forum of Poetics”, nr 10, s. 66-91, https://doi.org/10.14746/fp.2017.10.26794.

Witen Michelle (2021), The Story of Brexit: Nostalgia in Parody Children's BrexLit, $\mathrm{w}$ : Brexit and Beyond. Nation and Identity, red. Ina Habermann, Daniela Keller, Narr Francke, Attempto Verlag GmbH, Tübingen, s. 145-166. 


\section{| Abstrakt}

\section{MaŁgorzata Rygielska}

„BrexLit” po włosku dla dzieci i dorosłych: Rosie e gli scoiattoli di St. James oraz La mia Londra Simonetty Agnello Hornby

Artykuł poświęcony jest porównaniu dwóch książek Simonetty Agnello Hornby ze szczególnym uwzględnieniem tematyki migracyjnej, którą autorka, urodzona w 1945 roku we Włoszech, a od 1972 roku mieszkająca na stałe w Wielkiej Brytanii, poruszała także w innych utworach. La mia Londra to autobiograficzny przewodnik po Londynie, w którym Hornby opisała na własnym przykładzie przebieg procesu adaptacji do życia w kulturze innej niż rodzima. Spędziła w tym mieście prawie pół wieku, z perspektywy czasu zwracając uwagę na zmiany, jakie zaszły m.in. w strukturze społecznej, relacji z imigrantami, stylu życia londyńczyków. Główną bohaterką opowieści dla dzieci Rosie e gli scoiattoli di St. James jest Rosalia Giuffrida-Watson, dziewięcioletnia córka londyńskich imigrantów (Włocha Bruna i Jamajki Brendy), która w dzień referendum dotyczącego pozostania Wielkiej Brytanii w Unii Europejskiej staje się świadkiem obrad parlamentu zwierząt w parku królewskim, a także walk jego mieszkańców: przybyszów i autochtonów. Ich poglądy, zachowania i decyzje pozwalają Rosie zetknąć się z problemami, ale i potencjałem, jakie niosą ze sobą procesy akulturacji, adaptacji kulturowej, a nawet - asymilacji. Tłem porównawczym dla rozważań są inne utwory wpisywane w nurt BrexLitu.

Słowa kluczowe: BrexLit; adaptacja kulturowa; akulturacja; różnorodność kulturowa; autobiografia; literatura dla dzieci

\section{| Abstract}

\section{MaŁgorzata Rygielska}

'BrexLit' in Italian for Children and Adults Rosie e gli scoiattoli di St. James and La mia Londra by Simonetta Agnello Hornby

The article is devoted to a comparison of two books by Simonetta Angello Hornby, placing it in the context of migration to which the author-born in 1945 in Italy and residing in Great Britain since 1972-has also touched upon in her other works. $\mathrm{La}$ mia Londra (My London) is an autobiographical guide to London, in which Hornby described, on the example of her own experiences, the process of adapting to life in a foreign culture. In retrospect, she spent almost half a century in this city, noting the changes in the social structure, relations with immigrants, and the lifestyle of 
Londoners. The main protagonist of the story Rosie e gli scoiattoli di St. James (Rosie and the Squirrels in St. James's Park) is Rosalia Giuffrida-Watson, a nine-year-old daughter of London immigrants (Bruno from Italy and Brenda from Jamaica) who, on the day of the referendum concerning Great Britain's future in the European Union, witness a session of animal parliament in the royal park and a clash between its residents: newcomers and autochthons. Their views, behaviour and decisions give Rosie an insight into the problems, but also the potential, connected to the processes of acculturation, cultural adaptation, and even assimilation. The cognitive context for the deliberations is provided by other "BrexLit" works.

Keywords: BrexLit; cultural adaptation; acculturation; cultural diversity; autobiography; children's literature

\section{| Biogram}

Małgorzata Rygielska - dr hab. w Instytucie Nauk o Kulturze Wydziału Humanistycznego Uniwersytetu Śląskiego, prof. uś. Jej zainteresowania naukowe skupiają się wokół teorii i historii kultury/historii kultur, antropologii literatury w Polsce i na świecie, historii myśli teoretycznokulturowej. Interesują ją także polsko-włoskie i włosko-polskie koligacje literackie. Autorka książek: Dwa guziki. Norwid i ewolucjonizm (2011), Przyboś czyta Norwida (2012), Monografia Ignacego Lubicz Czerwińskiego Okolica Zadniestrska. Studium kulturoznawcze (2019), współredaktorka tomów zbiorowych (m.in. Starość jako wyobrażenie kulturowe wraz z A. Gomółą) oraz autorka artykułów poświęconych dawnym i współczesnym badaniom kultury we Włoszech (m.in. „Dono del sangue”. The Research by Fabio Dei on the Cultural Conditions of Blood Donation in Italy, 2019; Narcyzm po włosku albo digitambulicy $i$ selfiści, 2020).

E-mail: malgorzata.rygielska@us.edu.pl; malgorzata.rygielska@gmail.com ORCID: 0000-0002-7723-7677 